\title{
Evaluation of Attention to the Pattern of Iranian Muslim Woman in Content of Religion and Life Books in Lower Secondary Schools
}

Evaluación de la atención al patrón de la mujer musulmana iraní en el contenido de los libros de religión y vida en las escuelas secundarias inferiores

\section{Razieh Haghgoo}

M.A. in Curriculum, Department of Educational Sciences, Shahed University, Tehran. Iran

Soolmaz Nourabadi*

Faculty member of Department of Educational Sciences, Shahed University, Tehran. Iran

* Correspondence

Email: nourabadi@shahed.ac.ir 


\section{Summary}

The present study has been compiled in order to analyze the content of the textbooks of Religion and Life in lower secondary school for attention to the formation of the Iranian Muslim Woman Pattern. The main purpose of this study is to investigate the content of religion and life textbooks in the lower secondary school on explaining the characteristics of the Iranian Muslim Woman Pattern for female students. To achieve this goal, content of this books analysis with William Romey method and then data gathered with researcher-made questionnaire and analyzed the results with using SPSS24 statistical software. The statistical sample of the study includes 306 female students and 19 teachers of religion and life lesson in lower secondary school in 9th district of Tehran who were studying and teaching in public schools. Findings indicate that there is a significant difference in the views of students and teachers regarding the content of this books. In such a way that the students had a more favorable view of the content of this books in reaching the pattern of the Iranian Muslim Woman, while from the teachers' point of view, the content of this books does not help us enough to reach the pattern of the Iranian Muslim Woman. The results of the quantitative analysis by the researchers indicate that the content of three books of religion and life in lower secondary school is primarily in the category of "monotheism and theism", "religious ethics", "rules" and then "women, family and society". And the content of the books is lacking in terms of guiding students to reach the pattern of Iranian Muslim Women.

Keywords: Pattern of Iranian Muslim Woman, Lower Secondary School, students, Teachers, Religion and Life Books.

\section{Resumen}

El presente estudio ha sido compilado con el fin de analizar el contenido de los libros de texto de Religión y Vida en la escuela secundaria inferior para la atención a la formación del Patrón de la Mujer Musulmana Iraní. El objetivo principal de este estudio es investigar el contenido de los libros de texto de religión y vida en la escuela secundaria inferior para explicar las características del patrón de la mujer musulmana iraní para las estudiantes. Para lograr este objetivo, el contenido de este libro se analiza con el método de William Romey y luego se recopilan los datos con un cuestionario elaborado por el investigador y se analizan los resultados con el uso del software estadístico SPSS24. La muestra estadística del estudio incluye 306 alumnas y 19 profesoras de religión y lecciones de vida en la escuela secundaria inferior en el noveno distrito de Teherán que estudiaban y enseñaban en escuelas públicas. Los resultados indican que existe una diferencia significativa en las opiniones de estudiantes y profesores con respecto al contenido de estos libros. De tal manera que los estudiantes tuvieron una visión más favorable del contenido de estos libros para alcanzar el patrón de la Mujer Musulmana Iraní, mientras que desde el punto de vista de los docentes, el contenido de estos libros no nos ayuda lo suficiente para llegar a la meta. patrón de la mujer musulmana iraní. Los resultados del análisis cuantitativo de los investigadores indican que el contenido de tres libros de religión y vida en la escuela secundaria inferior se encuentra principalmente en la categoría de "monoteísmo y teísmo", "ética religiosa", "reglas" y luego "mujeres, familia y sociedad ". Y el contenido de los libros es deficiente en términos de guiar a los estudiantes para que alcancen el patrón de las mujeres musulmanas iraníes.

Palabras clave: Patrón de mujer musulmana iraní, Bachillerato, estudiantes, Maestros, Religión y Libros de la vida.

\section{Introduction}

Undoubtedly the family is the first, the most important and the main school for the individual and is one of the main educational institutions of the society. Therefore, expressing any words and thoughts 
about training of children and adolescents and having any expectations from them, regardless of the vital role of the family, are considered incorrect words and thoughts and the expectations are useless (BehPazhooh, 2018). People learn how to live within the family. Men and women play the most important role in the family, because they are responsible for educating their children. Children who in the future, will become the parents of other families. As a result, parents have a very serious responsibility; because their training determines the training of the next generation and the state of society.

According to this important principle that "man is multidimensional being, and does not have only one dimension" (Berg, 2014); Education, both in the family and at school, should be such that it encompasses various aspects of human beings and not only pays attention to the growth and development of the material aspect, but should also include the spiritual aspect in education to the same extent. Education in the family and at school must be sustainable in such a way that the child grows in an all-round manner. According to the above and considering the fact that the curriculum planning system in Iran, despite the different cultures in the country, is centralized and all teachers are required to implement a centralized curriculum. As a result, the type of content that written in textbooks, plays a very important and fundamental role in determining the type of view of society towards Iranian Muslim Women.

Since the serious task of education is the responsibility of the school and the family, it is necessary to pay attention to the content of the textbooks. Among these, the lower secondary school, which includes the seventh, eighth and ninth grades; is a critical period for students. Because adolescents in this period seek to gain identity and independence, so in this period should be paid more attention to them (Panahi, 2018). As a developing country, Iran focuses on training its future manpower, and since half of the country's population is made up of women, it means that half of the country's workforce are women. Therefore, in order to use all the potentials and capabilities of a Muslim Woman, while maintaining dignity, honor and independence, must have plan; and for planning, a pattern is needed. So in addition to realizing the current situation for the future, can be determined certain criteria. On the other hand, considering that the school is the second most influential institution in educating children; the attitude of teachers, teaching staff, and the content of the books, play a very important and influential role in raising children. Therefore, due to the centralized educational system of Iran, the type of content that written in the books, is important in educating children. So the design and production of content of books should be done by experts and specialists.

In the following, some researches in this field show the importance of paying attention to the Pattern of Iranian Muslim Women. Bajestani and Ravahani Mogadam (2019) have conducted a study entitled "The lifestyle of Iranian Muslim Women in the thoughts of Supreme Leader". In this study, lifestyle is a regular set of individual actions that embodies a particular narrative of identity attributed to the individual to others. The Muslim man, and especially the Muslim woman, chooses his daily performance within the framework of the do's and don'ts of Islamic law. This practice, which is based on Islamic teachings, depicts the Islamic lifestyle of a Muslim woman. The Supreme Leader has portrayed this lifestyle for the women of the Islamic society on various occasions and in numerous speeches. A descriptive analytical study of the views of this prominent and examination of his statements and guidelines indicates that the lifestyle of Iranian Muslim women can be examined in three basic forms: individual, social and family lifestyle. This article aims to explain the lifestyle of Muslim women in the thoughts of Supreme Leader's and outlines the most important components of this issue in the above three areas.

Warren (2019) examines "Muslim fashion media and lifestyles and their impact on reshaping the global media, leisure, entertainment, and identity space of Western and European liberal societies". This article specifically mentions highly educated British Muslim women as producers of cultural products in the media and fashion, and describes their efforts to find strategies to challenge stereotypes about Muslims, and resistance to their social and economic exclusion. It also offers solutions for the educational and professional advancement of Muslim women in emerging and creative fields by discussing gender issues and creative activities. 
Shahparipour (2018) has conducted a study entitled "The image of the role of Iranian women in the Islamic-Iranian model of progress". Women on the planet, like men, have had roles commensurate with their existence, among which the most attention is paid to the social role of women versus men, and this attention is mainly seen among feminists; but religion, society, custom and law have each addressed the roles that women can play. In a religious government where social jurisprudence is observed; Women's roles such as education, political participation, marriage, childbearing, child rearing, housekeeping, worship, and employment have received considerable attention. In Islamic government, in order to achieve progress, one should not follow the epistemological foundations of the West, but progress is created in the shadow of Islamic teachings, and to achieve this Islamic progress, we must have an internal and local basis based on IranianIslamic identity. That is, worldly progress to achieve worldly and otherworldly happiness.

Kouhsari et al. (2017) have conducted a study entitled "The role of mothers in promoting the Iranian-Islamic lifestyle". This article is about the role of mothers in promoting the IranianIslamic lifestyle. In this article, it is believed that mothers play an important role in promoting the Iranian-Islamic lifestyle. This descriptive-analytical study using different sources shows that if we want to promote a certain lifestyle in a society, we must first focus on families, especially the role of mother. It is true that in the present age, the educational environment and the media also have a tremendous impact on lifestyle. But if we are careful, we find that the influence of the educational environment and the media are not to the power of the family, and in addition, their influence is partly due to the will of families. Lifestyle is so important that it can be the basis of civilization and culture of a society.

So, the main question of this study is: To what extent can the content of the textbooks of Religion and Life in lower secondary school help adolescent female students to become an Iranian Muslim Woman?

\section{Methodology}

In this research, the type of research is an application that has been done by descriptive-survey method. Quantitative counting is also done through free content analysis. For this purpose, at first, the content analysis of the books of religion and life in lower secondary school was done with using the method of quantitative analysis. In the following, an attempt has been made to determine the degree of engagement coefficients of the text and the questions contained in it using the method of quantitative content analysis of William Romey, as well as the whole content based on the categories defined in the quantitative counting method. The book- both in the text and in the question- should be adequately and thoroughly reviewed. In this way, an attempt has been made to determine the success rate of this book in accurately explaining the components of the Iranian Muslim Woman Pattern. Then, by distributing the researcher-made questionnaire among teachers and students, as textbooks of religion and life of the lower secondary school, their opinions in this field were obtained and the results were compared with the analyzes performed. It should be noted that according to Krejcie and Morgan's table, for a community of 1650 female in lower secondary school students in education district of 9; 306 students were randomly selected as a sample, and for a community of 20 religion and life lesson teachers, 19 of them were randomly selected as a sample. After presenting the questionnaires and receiving the results of the questionnaires, the data obtained with using SPSS24 software, were analyzed based on t-test. It should be noted that the validity of the questionnaire was confirmed by receiving the points of view of several professors of curriculum planning and the reliability was obtained 0.84 by using Cronbach's alpha coefficient.

\section{Findings}

According to the topics discussed in the textbooks of religion and life of each grade (seventh, eighth and ninth grade), and considering the designation of "Iranian Muslim Woman Pattern" as the main 
component in order to categorize and prepare content codes to begin the analysis of this, The units are classified and discussed in 4 subcategories: "monotheism and theism", "religious ethics", "woman, family and society" and "rules". It should be noted that according to the characteristics of an Iranian Muslim Woman in terms of verses, hadiths and sayings of elders, which include theology, heart and practical belief in God and the Prophet and following his instructions, having a good morals and appropriate mood according to the precepts of religion are continuous and simultaneous presence and activity in the family and social spheres, as well as having sufficient knowledge of the rules of Islamic Sharia and adherence to their correct and complete performance. These four subcategories were defined under the title of the Pattern of Iranian Muslim Women.

The content units of the research were determined separately in each book and were assigned to each of these four categories separately based on thematic appropriateness. Then, in order to obtain appropriate and acceptable reliability on the one hand and on the other hand to gain sufficient knowledge about the type of positive or negative attitude towards the selected unit of content in the book, the contextual unit was considered as a paragraph in each case. According to the content units, contextual units and categories defined in the previous section, the percentage of contextual units that have each of the four categories related to the component of the Iranian Muslim Woman Pattern has been determined in the text and questions. Then, the results were analyzed by William Romey method and documentary comments were presented. Finally, the results of the questionnaires were analyzed and the processed data were analyzed with using SPSS24 software and the results were matched with quantitative content analysis and William Romey content analysis and completed.

- Quantitative Content Analysis of the Seventh Grade Book:

In this book, 81 contextual units were identified in the text in the studied categories, that 7 units contained active content and the rest were inactive units. Also, 84 content units were obtained in the queries, of which 37 units were active and the rest were inactive. About forty percent of the text of the seventh grade book is related to religious ethics and its related components, and the other three categories are almost equal, each accounting for about 20 percent of the text of this book. This indicates the primary importance of this category in this book. The noteworthy point in this book is that in relation to the characteristics of Muslim Women in the form of expressing the personal, family and social characteristics of Holiness Fatemeh Zahra, the necessary points and materials have been briefly presented. Although quantitatively comprising an almost acceptable proportion of the content taught, it has done little to relate the virtues mentioned by the Prophet to the day-to-day issues that adolescent and young girls are involved with.

Also, according to the results of William Romey's method of analysis and according to the text engagement coefficients in all four categories, which are numerically between 0 and 0.14 , it is clear that the text of the book is a non-research text that only provides information on the topics and only in a few cases, it has challenged students by asking active questions within the text. On the other hand, considering the coefficients of engagement of the questions in the first three categories, which are numbers between 0.8 to 1 , it is clear that the task of dynamics and activity of the content and engaging students with the text is assigned to these questions, which can be considered a weakness. This is because it reduces the dynamics of the whole content in each category as well as the whole book (considering the total conflict coefficients in each category which is a number of about 0.4 and somehow indicates that the content as a whole has about $30 \%$ dynamics). In addition, even in the issues related to the category of rulings, even this dynamics in the questions is not very noticeable (the coefficient of involvement of the questions from about $0.8-1$ to 0.46 , and the total coefficient has decreased from 0.4 to 0.2 ). In these topics, most of the questions are more in the form of reviewing the content and providing information.

- Quantitative Content Analysis of the Eighth Grade Book:

In this book, 87 content units were identified in the text in the studied categories, of which 8 units contained active content and the rest were inactive units. Also, 93 content units were obtained in the queries, of which 47 units were active and the rest were inactive. Considering that the topics related to the categories of monotheism, theism, and religious ethics in this eighth grade book, both in the original text and in the questions, account for about $70 \%$ of the educational content of the books; it is clear that the predominant attitude of the authors in writing the textbook. The foundation 
of this book is based on the definition of the main doctrinal and monotheistic principles as well as Islamic moral concepts. Also in this book, as in the seventh grade, except in special cases that deal specifically with issues related to the religious, moral and social duties of women, in the rest of the material, the common religious concepts among all students are discussed. In addition, the same amount, unlike the seventh grade book, which had a relatively desirable share of $20 \%$ of the content, has been reduced to one third and has reached about $7 \%$ of the total text (the same is true for questions with the benefit of only $6 / 4 \%$ of the questions are visibly noticeable). In the section of rulings, the authors have provided more supplementary material on religious issues related to adolescents mentioned in the previous book and have reduced the volume of new material, and therefore the percentage of this material both in the text and in the questions from $20 \%$ to about $16 \%$ to $17 \%$ decreased. Subsequently, in this book, the emptiness of the discussion regarding the rulings related to Muslim Women is evident, and apart from presenting a few lines of information about incest, there is nothing else in this regard regarding women.

Also, according to the involvement coefficients of the categories mentioned in the text, which is between 0 and 0.15 ; as in the seventh grade book, it is clear that the text of the book is a non-research text based on direct presentation of curriculum with the least involvement and participation of students in understanding the curriculum, which is still the main burden of dynamism and student participation in teaching. Responsible for questions and classroom activities at the end of lessons. Regarding the issue of religious ethics, due to the low coefficient of engagement of 0.07 text and the coefficient of engagement above 1.7 questions, which in a way indicates an excessive increase in analytical and dynamic questions in classroom activities and questions; There is a big difference between the way the text is written and the way the questions are written, which may confuse students in the way they teach the material. In this way, the overall dynamics of the content, which is desirable at 0.65 , will be reduced. Regarding the issue of women and family, which is one of the most basic categories studied in this study and in the discussion of the pattern of Iranian Muslim Women, in this book, only a few pages are limited to talking about hijab and chastity and incestuous rulings. It is clear that even this little material is limited to providing pure information and lacks any dynamism and effort to involve students in research. Meanwhile, in the discussion of questions, only three questions have been asked, only one of which has been dynamically posed in the form of classroom activities, and openly, there is not enough competence to involve students in the topics discussed in this section. It should be noted that in the category of rulings, like the seventh grade book, this book suffers from a lack of necessary dynamism and vitality.

- Quantitative Content Analysis of the Ninth Grade Book:

In this book, 102 content units were identified in the text in the studied categories, which 15 units contained active content and the rest of the units were inactive. Also, 80 content units were obtained in the queries, of which 38 content units were active and the rest were inactive. In the ninth grade book, according to the obtained results, it is clear that about $50 \%$ of the material is devoted to the categories of monotheism, theism and religious ethics, and other topics such as jihad, Islamic Revolution, cultural ambush, leadership and leadership duties and the issue of waiting for Holiness Mahdi alone as the most important issues studied in this book has accounted for about $35 \%$ of the content. Therefore, it is clear that the type of attitude of the authors in this book is to reduce the level of presentation of the material about the first two categories and to suffice to complete the information provided in this field in the previous textbooks and finally to present some new material. Instead, the book focuses on newer, lesser-known issues. On the other hand, it seems that in this book, the share of religious rulings has been reduced again (about 13\% of the total book) and this section has been replaced with materials related to Mahdism and the Islamic Revolution. The important point in this regard is that in this book, in the topics related to the categories of monotheism, theism and religious ethics, it has only presented materials related to the beliefs and moral principles of the Muslim public, and specifically about Muslim women. It has not been mentioned. The Shari'a rulings have also been neglected to mention the Shari'a rulings related to teenage girls. Also about the category of women, family and society and the huge capacity that 
existed in explaining the role and position of women in the revolution and the groundwork for the emergence of Holiness Mahdi, it was expected that in this book the authors would at least address issues such as the role of women in war. Jihad and defense of Islam and the Islamic homeland, how they played a role during the Islamic Revolution and their efforts to achieve this revolution, Mahdism and the role of women in the growth and excellence of society during the absence of the Imam and discussions of they should make sure that such a thing is not seen openly in the book, and it is safe to say that the attention paid to the specific features of an Iranian Muslim woman in this book is zero or close to zero.

Also, according to the coefficients of conflict of categories in the text of the book, which is from 0 to 0.28 , it is clear that although in the subject of sentences with a coefficient of conflict 0 , a completely non-research and inactive text is still observed; However, in the categories of Mahdism and the Islamic Revolution and religious ethics, with 0.28 and 0.19 conflict coefficients, respectively, more active and participatory questions are presented in the text and more efforts are made to increase the dynamics of the text, but still the text in these categories and monotheism and theism, it is a non-research text based on the direct presentation of content and concepts. It should be noted that increasing the text engagement coefficient to 0.28 in the subject of Mahdism and the Islamic Revolution can be more than the content of the Islamic Revolution, expectation and Mahdism and the inherent need of these categories to have a little dynamism in writing texts.

In this book, the dynamics of the questions in each of the categories has conflict coefficients between 0.57 and 1.37, which according to the total coefficient of conflict of 4 categories, which is equal to 3.65 -and about 0.4 more than the previous basic books- and the understanding that the lowest The coefficient of conflict of the rulings is 0.57 and the highest is monotheism and theism with 1.37. It can be seen that, firstly, a more appropriate distribution of the number of active questions in each section can be seen than previous books, so that none of the categories ( 0.4 to 1.5$)$ and this means that in all categories there is an acceptable distribution of questions in order to review the content (inactive) and questions involving students with teaching concepts (active). However, although the first three categories with conflict coefficients of 0.8 to 1.37 have been able to cover the weakness of the dynamics of the texts related to their topics and reach a total conflict coefficient of about 0.42 to 0.46 , but the category of sentences is still completely non-research text. (Involvement coefficient 0) and also less dynamics of questions (engagement coefficient 0.57 ) has less total dynamics (coefficient of 0.2) than other categories and is considered non-research and inactive.

- Analysis of the results of the distribution of questionnaires:

Due to the normality of the data distribution, which was proved by Kolmogorov-Smirnov test, the results of the questionnaires, which were designed based on the Likert scale method and in 5 degrees very low, low, medium, high and very high, based on T-test was analyzed in relation to each component of the Iranian Muslim woman model. A review of the results shows that regarding the status of attention to the pattern of Iranian Muslim Women in the content of the curriculum of religion and life textbooks in the lower secondary school based on teachers' views, there is a significant difference between the sample average $(\mathrm{t}=46.72)$. The results show that the average attention to the pattern of Iranian Muslim Women in the textbooks of religion and life in lower secondary school is moderate to low, because the average obtained is 2.59 less than the hypothetical average, i.e. the number 3. Also review of results shows that regarding the status of attention to the pattern of Iranian Muslim Women in the content of the curriculum of religion and life textbooks in the first year of lower secondary school based on students' views, there is a significant difference between the sample average and hypothetical average $(t=136.96)$. The results indicate that the status of attention to the pattern of Iranian Muslim women in the textbooks of religion and life in lower secondary school is above average, because the average obtained is 3.52 more than the hypothetical average, i.e. the number 3 .

\section{Conclusion}

According to the purpose of this study, which is to examine the content of the books of religion and life of lower secondary school from the perspective of matching the textbooks of these books with 
the components of the Iranian Muslim Woman pattern and according to the analysis and issues raised, it is determined that: These books, especially in the seventh and eighth grades, with an average of $62 \%$ of the contents of these books, are on topics related to monotheism, theism and religious ethics. About $21 \%$ of the content of these three books, on average, covers topics related to women, family and society, which, although seemingly a reasonable proportion of the book's teaching share is quantitative, but given issues related to this component are presented in the ninth grade book in the field of topics such as the Islamic Revolution, Mahdism, Jihad and soft war, and in these articles, the role and position of women in these fields are not mentioned. Therefore, in a way, this share can be reduced to about $9 \%$ of the total content of the book, which indicates the book's weakness in expressing content related to the pattern of Iranian Muslim Women. In relation to the Shari'a rulings and jurisprudential issues facing adolescents, an average share of about $17 \%$ of the content in the total of these three books has been considered. Exclusively for women, it has been avoided except in a few cases.

According to the conflict coefficients obtained from the results of analyzing the content of the book by William Romey method, it is generally clear that in the main content of the book in the textbook section, the content with conflict coefficients less than 0.4 has suffered from lack of dynamism and vitality. And it is a non-research and inactive text that the task of lacking this dynamism and vitality in the main parts of the book is assigned to the questions and class activities at the end of each lesson, which in itself can cause problems such as insufficient attention of teachers to design and review. These questions and activities at the classroom level due to the lack of teaching time and also create a kind of duality and conflict in the minds of students and ultimately lead to confusion in the correct understanding of the curriculum and understanding of the teaching materials taught by teachers.

The results of the questionnaires indicate that from the point of view of teachers, these books have performed poorly in explaining the pattern of Iranian Muslim Women, and in relation to women, their family and social duties have been mentioned very little and briefly, and in relation to specific ladies rulings, no details are mentioned at all. Regarding the category of monotheism, theism, and religious ethics, which account for the largest share in these three books, the material does not encourage students to learn. In general, the contents of the book do not have the necessary dynamism and vitality. However, the students had a favorable view of the content of the book, so that in their opinion, the content of this book has been successful in explaining the pattern of Iranian Muslim Women.

According to the researchers of this study, these three books have done very poorly in explaining the pattern of Iranian Muslim Women, so that only in the seventh grade book, the personal, family and social characteristics of Holiness Zahra as a pattern of a Muslim Woman are mentioned, but the content is not dynamic enough and does not address issues related to the current issues of girls and women in society. In the eighth grade book, only minor details are mentioned about hijab, which does not have the desired dynamism and comprehensiveness. In the ninth grade book, there is no mention of the role and duties of women in the family or society. In general, in relation to any of the components related to the Iranian Muslim Woman, the characteristics and features of the Iranian Muslim Woman are not fully and comprehensively mentioned. It should be noted that the research findings are alignment with the views of teachers, and in relation to students' opinions, it can be said that their positive view of the book is not only because of the content of the books; rather, it can stem from good teacher teaching, teachers' use of appropriate teaching tools, and teaching aids.

In general, it can be said that the content of the three books Religion and Life of lower secondary school in identifying the components of the Iranian Muslim Woman pattern and explaining it to female students and also creating heartfelt and practical beliefs in adhering to religious principles and Islamic rules for relatively weak adolescents. They have acted and the 
contents of these books mostly present a series of predetermined superficial contents that are not able to penetrate deep into the souls and hearts of adolescent boys and girls.

\section{References}

Bajestani, Maryam \& Ravahani Mogadam, Mohammad (2019). The Lifestyle of Iranian Muslim Women in the Thoughts of the Supreme Leader. Iranian Muslim woman in the mirror of the model of fifty years of progress.

BehPazhooh, Ahmad (2018). Principles of Establishing a Human Relationship with Children and Adolescents. 11th edition. Tehran: Danjheh.

Berg, Laura (2014). Developmental Psychology. Vol: 2. Translated by: Yahya Seyed Mohammadi. Tehran: Arasbaran.

Kuhsari, Mohsen; Amini, Sara; Amini, Sakineh; Saruni, Hamid (2017). The Role of Mothers in Promoting the Iranian-Islamic Lifestyle. The Second National Conference on the Status and Role of the Mother.

Panahi, Ali Ahmad (2018). The Role of Men and Women in the Family with an Islamic Approach. Qom: Seminary and University Research Center.

Shahparipour, Hadith (2018). The Role of Iranian Women in the Islamic-Iranian Model of Progress. 7th Iranian Islamic Model of Progress Conference; from the Basic Model to the Iranian Islamic Progress Model.

Warren, S. (2019). Your Average Muslim: Ruptural geopolitics of British Muslim women's media and fashion. Political Geography Journal, 69, 118-127. 